\title{
Field data and numerical simulation of btex concentration trends under water table fluctuations: Example of a jet fuel-contaminated site in Brazil
}

\author{
Elias Hideo Teramoto ${ }^{\mathrm{a}}$, Hung Kiang Chang ${ }^{\mathrm{b}, *}$ \\ a Laboratório de Estudos de Bacias, Centro de Estudos Ambientais, UNESP - Universidade Estadual Paulista, Av. 24A, 1515, Rio Claro, Sao Paulo, Brazil \\ b Departamento de Geologia Aplicada, Centro de Estudos Ambientais, UNESP - Universidade Estadual Paulista, Av. 24A, 1515, Rio Claro, Sao Paulo, Brazil
}

\section{A R T I C L E I N F O}

\section{Article history:}

Received 6 October 2016

Received in revised form 16 January 2017

Accepted 17 January 2017

Available online 18 January 2017

\section{Keywords:}

Mass-transfer

BTEX

LNAPL saturation

Water table fluctuation

Smear zone

\begin{abstract}
A B S T R A C T
Mass transfer of light non-aqueous phase liquids (LNAPLs) trapped in porous media is a complex phenomenon. Water table fluctuations have been identified as responsible for generating significant variations in the concentration of dissolved hydrocarbons. Based on field evidence, this work presents a conceptual model and a numerical solution for mass transfer from entrapped LNAPL to groundwater controlled by both LNAPL saturation and seasonal water table fluctuations within the LNAPL smear zone. The numerical approach is capable of reproducing aqueous BTEX concentration trends under three different scenarios - water table fluctuating within smear zone, above the smear zone and partially within smear zone, resulting in in-phase, out-of-phase and alternating in-phase and out-of-phase BTEX concentration trend with respect to water table oscillation, respectively. The results demonstrate the model's applicability under observed field conditions and its ability to predict source zone depletion.
\end{abstract}

(c) 2017 Elsevier B.V. All rights reserved.

\section{Introduction}

In a source zone, the presence of entrapped or residual non-aqueous phase liquid (NAPL), including light non-aqueous phase liquid (LNAPL) and dense non-aqueous phase liquid (DNAPL), in direct contact with water is responsible for the continued release of soluble contaminants into the water (Miller et al., 1990; Cline et al., 1991; Dobson et al., 2007; Liu et al., 2012; Kokkinaki et al., 2013; Mobile et al., 2016). The presence of LNAPL in aquifers is often related to the accidental release of petroleum fuels into the subsurface. Whenever a large volume of hydrocarbon reaches the saturated zone, it can displace the water in the pores. LNAPL tends to accumulate above the water level. However, the water level may rise and fall as a result of alternating wet and dry seasons, which may lead to a vertical redistribution of the LNAPL as it migrates to lower parts of the aquifer when the water level declines (Kemblowski and Chiang, 1990; Charbeneau, 2007; Jeong and Charbeneau, 2014). When the water level rises, LNAPL is retained by capillary force in the saturated zone, a phenomenon known as trapping (Farr et al., 1990; Lenhard and Parker, 1990; Marinelli and Durnford, 1996; Kemblowski and Chiang, 1990; Charbeneau, 2007). When trapping occurs, LNAPL becomes entrained in the saturated zone; in contrast, when the water level drops, the LNAPL is released and the previously isolated drops and ganglia agglutinate gain mobility.

\footnotetext{
* Corresponding author.

E-mail address: chang@rc.unesp.br (H.K. Chang).
}

The movement of soluble compounds from the NAPL to the water is a rate-limited (non-equilibrium) mass transfer phenomenon. The total mass that is transferred from the entrapped NAPL can be calculated by multiplying the concentration driving force by the mass transfer coefficient and the specific interface area between the phases (Miller et al., 1990):

$\mathrm{J}=\frac{d C_{a}}{d t}=k_{a} a_{n w}\left(C_{s}-C\right)$

where $\mathrm{J}=$ flow of mass from residual hydrocarbons to the water $\left(\mathrm{ML}^{-2} \mathrm{~T}^{-1}\right), k_{a}=$ coefficient of mass transfer $\left(\mathrm{LT}^{-1}\right), C_{s}=$ maximum aqueous concentration of soluble compound $\left(\mathrm{ML}^{-3}\right), C=$ aqueous concentration of soluble compound ( $\mathrm{M}$

$\left.\mathrm{L}^{-3}\right)$ and $a_{n w}=$ area of specific interface between the water and NAPL $\left(\mathrm{L}^{2}\right)$.

The interface area $\left(a_{n w}\right)$ corresponds to the area of contact between two immiscible fluids in a given pore volume unit. Various authors (Anderson et al., 1992; Saripalli et al., 1998; Saba and Illangasekare, 2000; Dobson et al., 2007; Culligan et al., 2004; Cho and Annable, 2005; Cho et al., 2005) emphasize the need to estimate this parameter to understand the dissolution of NAPL in groundwater. The dependence of $a_{n w}$ on the saturation of the water $\left(S_{w}\right)$ and capillary pressure $\left(P_{c}\right)$ in a porous medium has been determined using thermodynamic models and laboratory experiments (Held and Celia, 2001; Culligan et al., 2004; Brusseau et al., 2007; and Brusseau et al., 2009). Thermodynamic models for the estimation of $a_{n w}$ on the basis of drainage and absorption 
have been presented (Grant and Gerhard, 2007; Porter et al., 2010; Kokkinaki et al., 2013). These models are based on the premise that the work involved in absorption and drainage is transformed into the formation or breakdown of the NAPL-water interface. The work of Brusseau et al. (2009) showed this relationship experimentally, as well as the existence of a linear relationship between $a_{n w}$ and the mean diameter of the grains for different types of geological materials.

Mass transfer will occur until the concentration equilibrium between water and NAPL is reached. NAPL represents a multi-component system and, in most cases, consists of complex mixtures of organic compounds with different solubility values, which makes their dissolution more complex than that of a simple compound and the concentration of individual organic compounds in equilibrium with the water in contact with the NAPL. The equilibrium concentration depends on the composition of the mixture, as demonstrated by Banerjee (1984) and Mackay et al. (1991). The solubility of each compound is less than the solubility of the pure substances in water and can be determined in a porous media with two immiscible liquids using Raoult's law:

$C_{i, s a t}=\chi_{i, o} \gamma_{i, o} S_{i}$

where $C_{i, s a t}=$ concentration of compound $i$ in the water ( $\left.\mathrm{mol} / \mathrm{L}\right), \chi_{i, o}=$ molar fraction of compound $i$ in the mixture, $\gamma_{i, o}=$ coefficient of activity of compound $i$ in the mixture, and $S_{i}=$ maximum solubility of compound $\mathrm{i}$ in the water $(\mathrm{mol} / \mathrm{L})$.

The equilibrium concentration of aqueous compound depends on the activity coefficient $\left(\gamma_{i, o}\right)$ of the compounds in the mixture, which may change with time. Several works (Cline et al., 1991; Eberhardt and Grathwohl, 2002; Luthy et al., 1993; and Chrysikopoulos \& Lee, 1998 ) state that $\gamma_{i, o}$ is 1 or close to 1 for aromatic hydrocarbons, although this value may be valid only for thermodynamically ideal solutions. Ghoshal et al. (1996), Lee and Chrysikopoulos (1998), Lee and Chrysikopoulos (2006), Liu et al. (2012) and Lekmine et al. (2014), for example, have shown that $\gamma_{i, o}$ may be different from 1 and is a function of the molar fraction of the compound in the mixture $\left(\chi_{i, o}\right)$. Lekmine et al. (2014) verified experimentally that the values for $\gamma_{i, o}$ for fresh gasoline vary from 1.2 to 1.4 , whereas those of weathered gasolines vary between 1.0 and 1.2 .

The role of lithological properties on the distribution and dissolution of NAPL has been explored by various authors, including Zhang et al. (2007), Kueper et al. (1989), Illangasekare et al. (1995), Miller et al. (1990), Saenton et al. (2002) and Farthing et al. (2012). NAPL accumulates in coarse sand layers, whereas those of fine sand serve as capillary barriers. Powers et al. (1994), Imhoff et al. (1994) and Zhang et al. (2007) show a positive correlation between the amount of transferred mass and mean grain size, indicating an increase in the dissolution of NAPL in response to an increase in the pore dimension. Zhang et al. (2002) suggest that in coarse sand, the distribution of NAPL blobs in the pore allows the water flux to bypass more efficiently, and the interfacial area of contact with NAPL will be higher.

The dissolution of NAPL is also sensitive to variations in the flow rate in the porous medium. An increase in the dissolution rate as result of an increase in the flow rate has been experimentally determined by Geller and Hunt (1993), Powers et al. (1992), Seagren et al. (1999) and Saba et al. (2001). Saba et al. (2001) relate the increase in dissolution with the formation of water flow fingers in the NAPL bodies with an increase in the flow velocity.

Most of reviewed works use an empirical coefficient to estimate the dissolution kinetics of a non-aqueous phase known as the Sherwood number $(S h)$. As described by Miller et al. (1990), the parameter $S h$ is related to the properties of the porous medium, the Reynolds number and the volumetric fraction of NAPL. A modified version of the Sherwood number known as Sherwood-Gilland number has been frequently employed to calculate the interphase mass transfer (Eq. (3)):

$S h^{\prime}=\frac{k_{L} d_{m}^{2}}{D^{*}}=b \cdot R e^{c} \cdot S_{N}{ }^{d}$

where $k_{L}$ is the coefficient of the overall mass transfer rate $(1 / \mathrm{T})$; $\mathrm{dm}(1 /$ $\mathrm{L}$ ) is the average diameter of particles; b, c and d are empirical coefficients; $D^{*}$ is the coefficient of the molecular diffusion in water $\left(\mathrm{L}^{2} / \mathrm{T}\right)$; $R e$ is the Reynolds number and $S_{N}$ is the NAPL saturation.

The Sherwood-Gilland number $\left(S h^{\prime}\right)$ is normally incorporated into modified versions of transport models to simulate mass transfer on a bench scale. The applicability of $S h^{\prime}$ is shown in several works, such as Saenton et al. (2002), Mayer et al. (1999), Powers et al. (1994), Imhoff et al. (1994), Zhang et al. (2008), Saba et al. (2001), Miller et al. (1990), Zhong et al. (2003), and Kokkinaki et al. (2013). However, the $S h^{\prime}$ parameter is the result of the empirical calibration of numerical models and is valid only for specific problems for which the parameter is adjusted. Their applications on a field scale remain an open issue (Mobile et al., 2016). Moreover, the $S h^{\prime}$ parameter does not explicitly consider the water-NAPL interface area $\left(a_{n w}\right)$ and is thus a source of error for the Sherwood-Gilland number (Kokkinaki et al., 2013).

One alternative approach to simulate the mass transfer of NAPL to water is presented in the work of Liu et al. (2012), who proposed a model to calculate the aqueous hydrocarbon concentration as a function of NAPL compositional changes. The parameters of the model of Liu et al. (2012) were adjusted by experiments conducted in a 500-mL glass cell reactor containing a synthetic mixture of hydrocarbons. Mobile et al. (2016) used a code that includes an NAPL-dissolution source term coupled to the solute transport governing equation to reproduce NAPL dissolution on a field scale. The results of Colombani et al. (2009) and Mobile et al. (2016) provide evidence that it is possible to quantify NAPL dissolution within a source zone on a field scale directly using the mass-transfer coefficient.

Although the role of a large variety of influential factors on the mass transfer phenomena has been well documented, the impact of the water table is still underestimated. Only a few works using either numerical simulation (Reddi et al., 1998), laboratory experiments (Dobson et al., 2007) or field evidence (Davis et al., 1993; Kehew and Lynch, 2011; Zhou et al., 2015) have shown that dissolution is strongly controlled by water level fluctuations. These authors verified that the concentration of soluble hydrocarbons in water is correlated with the natural fluctuation of the water level, with an increase during the rise of the water level and a decrease during its fall. This behavior can be explained by the fact that a rise in the water level promotes saturation of the previously unsaturated zone enclosing residual LNAPL (Reddi et al., 1998; Dobson et al., 2007; Zhou et al., 2015). In the field, fluctuations in water levels, whether natural or induced by pumping, promote a large variation in the rate of LNAPL dissolution, and this cannot be ignored.

The complexity of the processes involved in the mass transfer of LNAPL to water tends to be greater in the field than normally admitted. The present paper presents an analysis of field data from continuous monitoring of the concentration of BTEX compounds in groundwater contaminated by jet fuel in an attempt to understand more thoroughly the dissolution of LNAPL. A conceptual model is proposed to explain the variations in the concentration of BTEX compounds in response to water level fluctuation, as well as an algorithm to simulate possible scenarios.

\section{Field site background}

The study area is located in the municipality of Paulínia, São Paulo, Brazil. A large volume of jet fuel is present in the subsurface, with an estimated volume of $520 \mathrm{~m}^{3}$ (Pede, 2009). This area has been investigated since 2002 with a pump-and-treat remediation system since 2005. Initially, it operated with four pumping wells. From 2008 to 2009, five additional wells were incorporated into the system. From 2010 to 2011, the remediation was paused and from 2011 to present, operation 
resumed with 20 active pumping wells. To determine the limit of LNAPL spread and the plumes of the dissolved phase of the BTEX compounds, 104 monitoring wells were installed in an area of $264,600 \mathrm{~m}^{2}$. Fig. 1 shows the poteciometric map, inferred limit of the source zone, location of the monitoring and pumping wells in the study area. The source zone occupied an area of approximately $80,000 \mathrm{~m}^{2}$.

\subsection{Hydrogeology setting}

The geology of the studied Cenozoic shallow aquifer is heterogeneously composed of clayey sands interfingered with coarse sand lenses, sandy clays and clayey silts. The geometry of the well-developed channel and floodplain facies indicate a depositional environment dominated by a meandering river (Teramoto and Chang, 2008; Pede, 2009; Teramoto, 2015). Because hydraulic conductivity is intrinsically related to aquifer lithology, a high variability of $\mathrm{k}$ is observed. Hydraulic conductivities determined by slug tests performed on 64 monitoring wells range from $1.2 \times 10^{-7} \mathrm{~m} / \mathrm{s}$ to $2.4 \times 10^{-4} \mathrm{~m} / \mathrm{s}$, with geometric mean of $2.8 \times 10^{-5} \mathrm{~m} / \mathrm{s}$. The average hydraulic gradient is 0.0036 in the northeast region and increases to the southwest, towards the discharge zone, reaching values of 0.0176 .

Fig. 2 illustrates the occurrence of alternating rainy (October to March) and dry seasons (April to September). Seasonal variation of rainfall precipitation generates a cyclic water-level fluctuation (Healy \& Cook, 2002; Maréchal et al., 2006; Delin et al., 2007; Neto et al., 2016). A time lag of nearly three months occurs in the studied area between the peak of the rainy season and the peak of the groundwater-level rise. The groundwater-level maximum is generally reached in May and falls steadily until December. The amplitude of the water level is directly related to the amount of annual accumulated rainfall (Teramoto, 2015).

The seasonal cycles of the fall and rise of the water table (Fig. 2) promote alternating cycles of trapping and release of non-aqueous phases in the pores. The upward movement of the water table during recharge can be understood as an imbibition event, because the wetting phase invades the pores and moves through the crevices of non-wetting lenses or ganglia. Thus, LNAPL is entrapped by snap-off or bypass mechanisms, restricting its mobility (Chatzis and Dullien, 1983). During the entrapment period, the decrease or even disappearance of the free phase thickness from the monitoring wells is observed. The downward movement of groundwater during dry seasons may be understood as a drainage event. The wetting phase entails the pores being drained and LNAPL being released and gaining mobility (Chatzis and Dullien, 1983; Marinelli and Durnford, 1996; Charbeneau, 2007; Jeong and Charbeneau, 2014). The freed LNAPL can migrate to monitoring wells and the free phase reappears or increases its thickness in these wells.
Fig. 3 illustrates the entrapment of LNAPL induced by water table fluctuations. The thickness of the free phase is generally smaller during periods of elevated water levels (Fig. 3a). The observed trend occurs in all monitoring wells located within the source zone. The smallest free phase thickness was recorded in May 2011, when the water table was at its highest level. The largest free phase thickness was recorded in December 2006, when the water table was at its lowest level. The interval of aquifer-containing LNAPL can be estimated knowing the maximum free phase thickness measured in a well (Charbeneau, 2007). The LNAPL interval as shown in Fig. 3b corresponds to the smear zone, which is separated into two portions - unsaturated (USZ) and saturated (SSZ) smear zones.

BTEX plumes resulting from LNAPL dissolution in source zone and transported dowstream are narrow, $<30 \mathrm{~m}$ along the flowpath (Fig. 1), with very low concentration ( $>10 \mathrm{ppb}$ ) due the high biodegradation kinetics. The large amount of iron oxides in the aquifer and high concentration of $\mathrm{Fe}^{2+}$ and $\mathrm{HCO}_{3}^{-}$in the source zone support the occurrence of microbial-mediated BTEX mineralization under Fe(III) reduction. The presence of $\mathrm{CH}_{4}$ in the source zone indicates the conjugated BTEX biodegration by methanogenesis (Teramoto and Chang, 2016).

\section{Material and methods}

\subsection{Field data}

Since 2002, the water level and free phase thickness have been measured with an interface probe with a biweekly frequency in the monitoring wells. This recorded time-series information has made it possible to construct hydrographs for each monitoring well. Because the physical properties of porous media have a significant role in mass transfer, aquifer characterization was executed using lithological data, hydraulic conductivity and retention curve parameters extracted from previous work (Teramoto and Chang, 2008; Pede, 2009; Teramoto, 2015 and Bordignon et al., 2015).

A monitoring program designed to collect water samples for the chemical analysis of all monitoring wells were conducted from May of 2006 to July of 2014, with a total 33 sampling campaigns. Groundwater was sampled using a low-flow methodology (USEPA, 1998). Samples were not collected in wells containing floating phase. Dissolved BTEX compounds in groundwater were determined by gas chromatography (GC/MS) using EPA method 8240B in a certified laboratory.

To identify the degree of LNAPL depletion, in 2014, the sampling of 13 selected wells was performed using a disposable bail sampler. The volatile organic compounds were extracted from the headspace of a $50 \mathrm{ml}$ vial containing the sampled LNAPL and analyzed by gas chromatography (GC/MS) using EPA method 8240B.

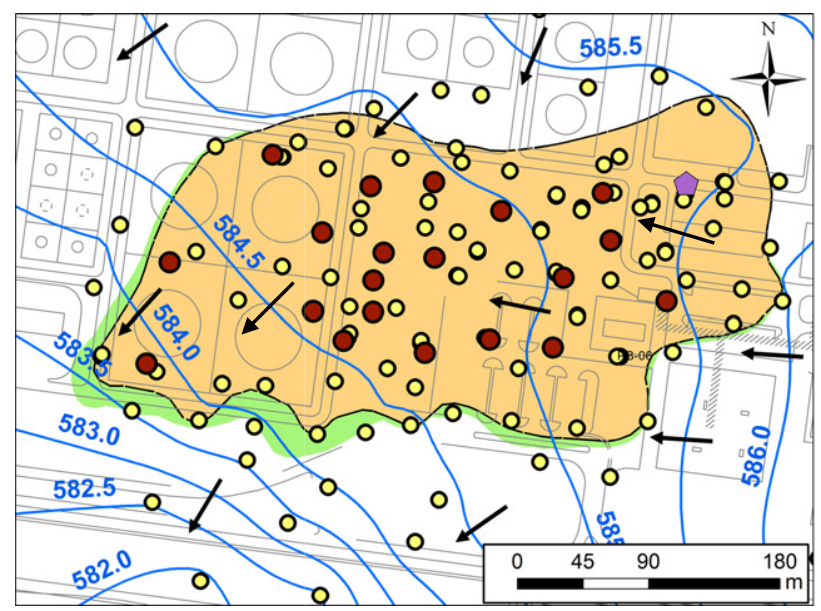

\section{Legenda}

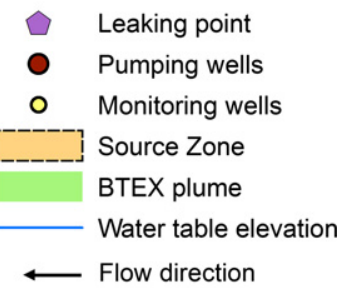

Fig. 1. - Location of monitoring and pumping wells in the study area and delineation of the source zone contaminated by LNAPL. 

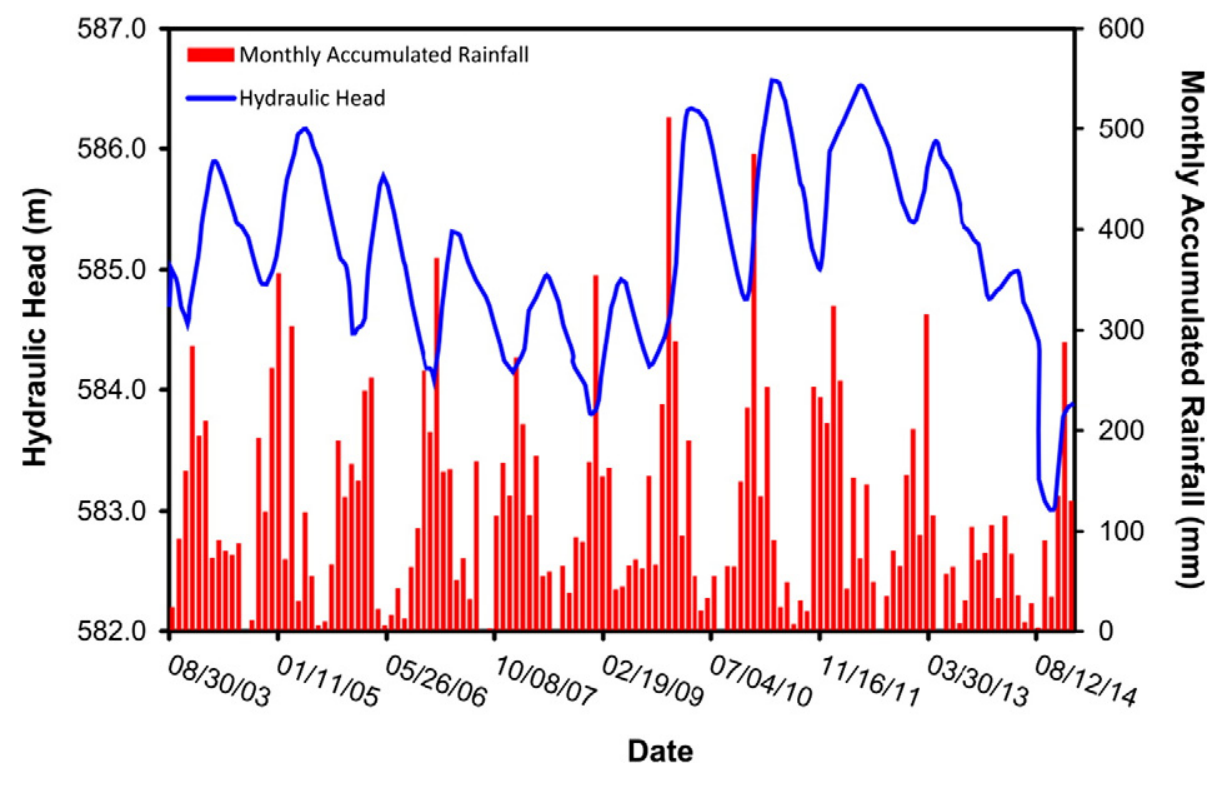

Fig. 2. - Hydrograph and annual accumulated precipitation recorded in a monitoring well distant from the pumping wells.

\subsection{Numerical model}

A conceptual model was elaborated to describe the temporal concentration trends of aqueous BTEX in response to water table fluctuations. To test the feasibility of the proposed conceptual model a set of simulations using a modified version of the numerical approach of Liu et al. (2012) (Eq. (4) to (7)) was performed. In Eq. (7), a biodegradation term was added imposing a first-order decay to reproduce the BTEX removal due the microbial-mediated mineralization.

$C_{i, e q, t}=\gamma_{i}\left(M_{i, t} / \sum_{j=1}^{m} M_{j, t}\right) \cdot S_{i, s u b}$

$E_{i, t}=A \cdot k_{i} \cdot\left(C_{i, e q, t}-C_{i, t}\right)$

$M_{i, t}=M_{i, t-1}-\frac{\Delta t}{2} \cdot\left(E_{i, t}+E_{i, t-1}\right)$

$C_{i, t}=\frac{\left(C_{i, t-1} e^{-\lambda \frac{\Delta t}{2}}\right)+\frac{\Delta t}{2 V_{w}} \cdot\left(A \cdot k_{i} \cdot C_{i, e q, t-1}+E_{i, t-1}-Q \cdot C_{i, t-1} e^{-\lambda \frac{\Delta t}{2}}\right)}{1+\frac{\Delta t}{2 V_{w}} \cdot\left(Q+A \cdot k_{i}\right)}$ where $C_{i, t}=$ aqueous concentration of compound i, $C_{i, e q, t}=$ equilibrium aqueous concentration of compound i, $M_{i, t}=$ mass in moles of the compound i (M), $\gamma_{i}=$ activity coefficient of compound i, $V_{w}=$ volume of water in the porous medium, $k_{i}=$ coefficient of mass transfer $\left(\mathrm{LT}^{-1}\right)$, $Q=$ flow $\left(\mathrm{L}^{3} \mathrm{~T}^{-1}\right), A=$ interface area $\left(\mathrm{L}^{2}\right), S_{i, \text { sub }}=$ solubility of compound $\mathrm{i}\left(\mathrm{M} / \mathrm{L}^{3}\right)$, and $E_{i, t}=$ exchange term of compound $\mathrm{i}(\mathrm{M} / \mathrm{T}) \cdot \lambda=$ first-order decay coefficient. The values of $C_{i}, C_{i, e q}, M_{i}$, and $E_{i}$, are marked by subscript $t$ and $t-1$ to account for current time step and previous time step, respectively.

In the scheme proposed by Liu et al. (2012), the non-linear system of Eqs. (4) to (7) is solved numerically using the Gauss-Seidel iterative method, with central weighting of time until convergence is reached. Because the algorithm of Liu et al. (2012) was developed to reproduce mass transfer in batch conditions, additional procedures were added to reproduce the effect of water table fluctuations in the REV-scale model. The unit volume was considered to be $1 \mathrm{~m}^{2}$ multiplied by the height of the smear zone.

The concentration-based interphase mass transfer is represented as a function of the water table position with respect to the smear zone in each time-step. The existence of two distinct compartments was assumed - a saturated smear zone (SSZ) and unsaturated smear zone
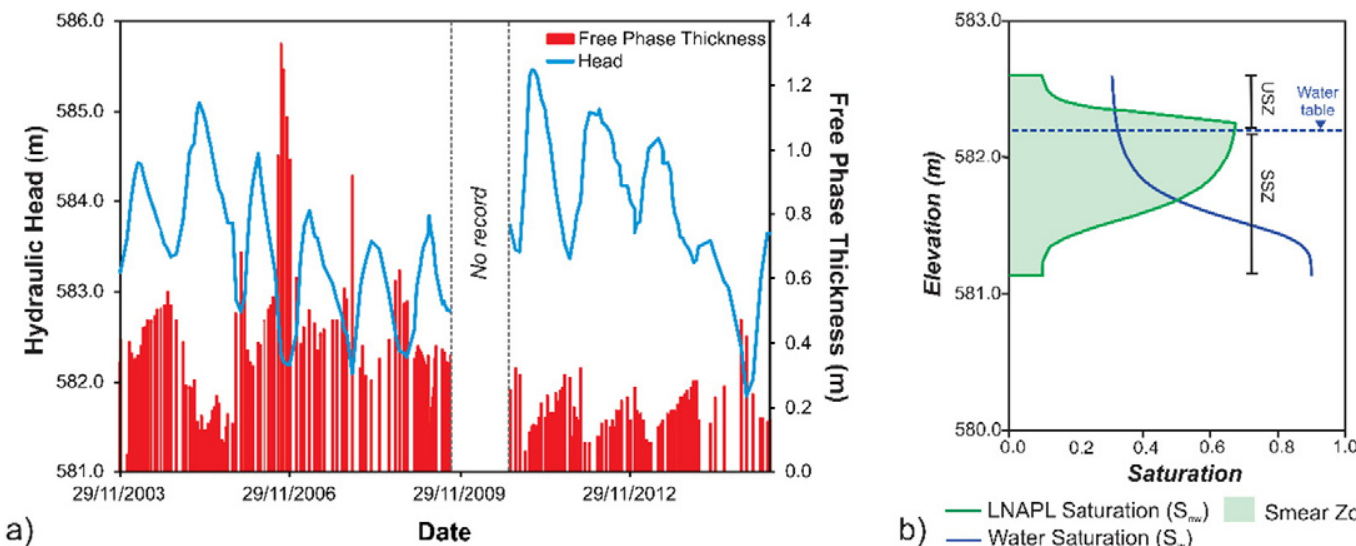

b) - LNAPL Saturation $\left(\mathrm{S}_{\text {mu }}\right) \quad$ Smear Zone

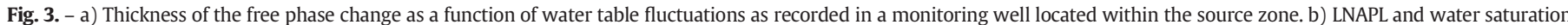

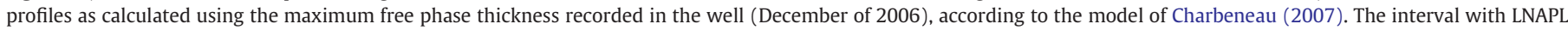

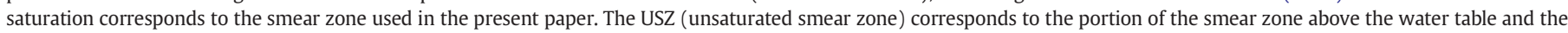
SSZ (saturated smear zone) corresponds to the smear zone bellow the water table. 
(USZ). To reproduce the dynamic effect of water table fluctuations on the BTEX concentration employing the proposed approximation, input parameters related to the position of the SSZ and USZ and hydraulic head variation over the simulation period are required. Hydraulic head $\left(\mathrm{h}_{\mathrm{t}}\right)$ and positions of both SSZ and USZ at each time step need to be specified. At each time step ht. is compared to the top of both SSZ and USZ. For ht. above the top of SSZ, mass is transferred from LNAPL within USZ to the groundwater using Eqs. (4) to (7).

It is assumed that the SSZ permanently releases BTEX into water because most of time this comportment is below the water table. Based on this assumption, the parameters A, Q LNAPL mass and $V_{w}$ of the SSZ are assumed to be constant throughout the simulation period. In contrast, the LNAPL of the USZ will release BTEX into water only when the water table lies within this compartment. For the sake of simplicity, the parameters of $A, Q$ and $V_{w}$ of the USZ are assumed to be linearly dependent of the height of water table within the USZ at time $t$, since the actual relationship between each parameter and the proportion of saturated USZ is not known.

At each time step, the remaining mass of the specific compound in LNAPL is updated and a new equilibrium aqueous concentration is calculated according to Raoult's law, keeping the mass of the LNAPL constant, because the molar fraction of the BTEX is small in jet fuel $(<0.013)$. In the case of the USZ, although only a portion is saturated, it is assumed that the BTEX loss will be distributed to the entire USZ for the purpose of facilitating numerical calculations.

The REV BTEX concentration corresponds to the weighted average $\left(C_{a v}\right)$ of these two compartments, as presented in Eq. (8).

$C_{a v}=\frac{\left(C_{S S Z} \cdot V_{S S Z}\right)+\left(C_{U S Z} \cdot V_{U S Z}\right)}{\left(V_{S S Z}+V_{U S Z}\right)}$

where $C_{S S Z}=$ concentration of compound $\mathrm{i}$ in the SSZ; $C_{U S Z}=$ concentration of compound $\mathrm{i}$ in the USZ $\left(\mathrm{M} / \mathrm{L}^{3}\right) ; V_{S S Z}=$ Water volume in the $\operatorname{SSZ}\left(\mathrm{L}^{3}\right)$; and $V_{U S Z}=$ water volume in the $\operatorname{USZ}\left(\mathrm{L}^{3}\right)$.
The optimized values for all parameters are obtained from manual trial-and-error calibration until the concentration curve was visually adjusted to the observed BTEX concentration in the monitoring well.

\section{Results and discussion}

\subsection{Source zone characterization}

The measured free phase thickness in monitoring wells may be used as a parameter to estimate LNAPL saturation in surrounding formations (Farr et al., 1990; Lenhard and Parker, 1990; Huntley et al., 1994; Marinelli and Durnford, 1996; Lundegard and Mudford, 1998; Charbeneau, 2007). Thus a high saturation of LNAPL is expected in the center of the source zone and a low saturation is expected in the border (Fig. 4).

The BTEX concentration in LNAPL (Fig. 5) shows a high spatial correlation with the free phase thickness (Fig. 4), suggesting a direct relationship between hydrocarbon saturation and BTEX depletion in LNAPL. Due to the large amount of LNAPL mass in the center of the source zone, BTEX has been less effectively depleted. This finding is in agreement with Eberhardt and Grathwohl's (2002) experiment, which demonstrated that NAPL dissolution can vary several orders of magnitude depending on the NAPL saturation in pores.

Fig. 5 shows the BTEX concentration in an aqueous phase within the source zone at the time of the maximum water level, which corresponds to the time of maximum entrapment. Despite the information being limited, the BTEX concentration in LNAPL follows approximately the same general trend of a decreasing concentration of dissolved BTEX in groundwater towards the edges of the source zone. The good correlation in BTEX between aqueous and non-aqueous phases reflects the well-known dependency of the dissolved aqueous BTEX concentration on the molar fraction of BTEX in LNAPL (Banerjee, 1984; Miller et al., 1990; Mackay et al., 1991; Borden and Kao, 1992; Cline et al., 1991; Eberhardt and Grathwohl, 2002).
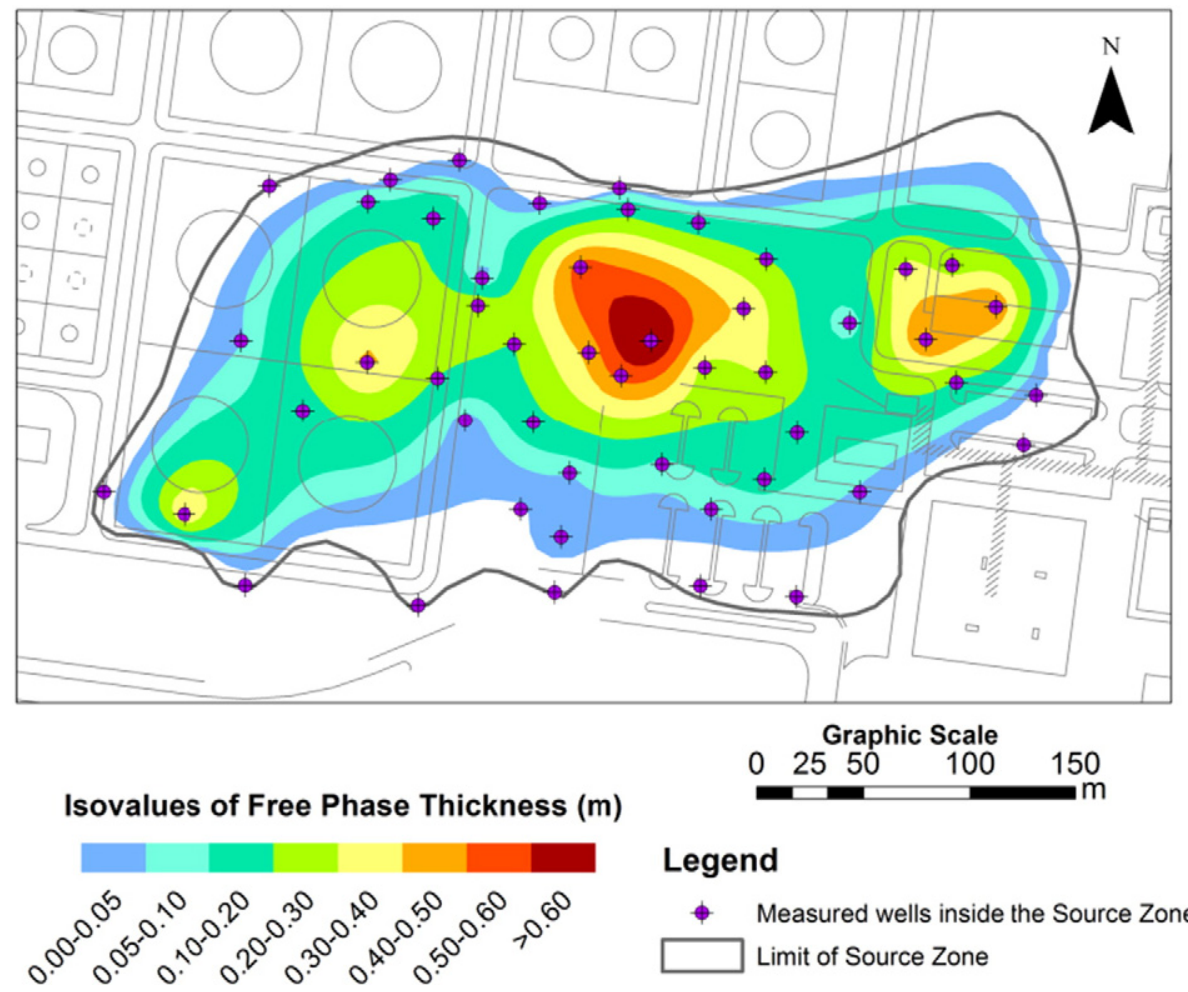

Legend

- Measured wells inside the Source Zone Limit of Source Zone

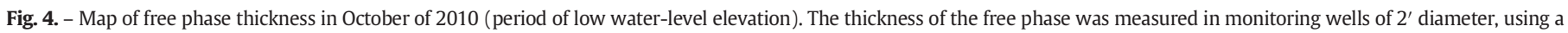
commercial dual-phase probe. The thickness of free phase is correlated with the amount of freed LNAPL 


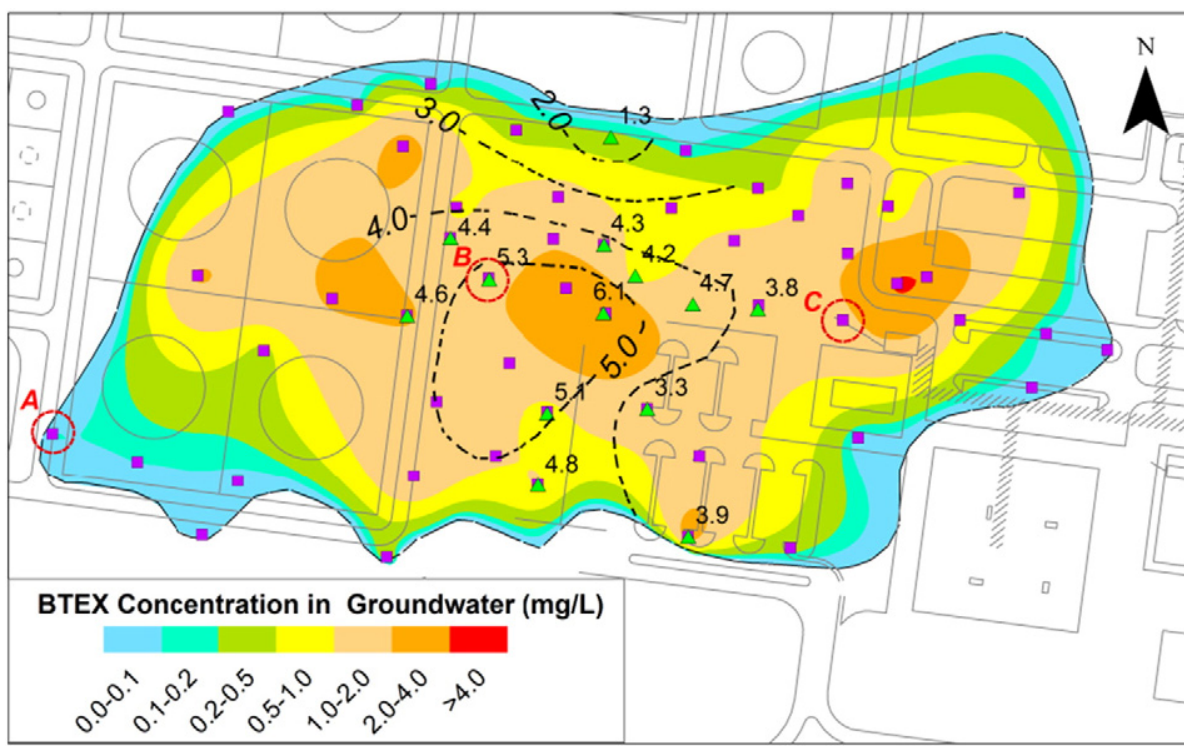

\section{Legend}

\begin{tabular}{l}
$-\quad$ Isovalues of BTEX in LNAPL $(\mathrm{g} / \mathrm{L})$ \\
BTEX Concentration in LNAPL $(\mathrm{g} / \mathrm{L})$ \\
- Sampled groundwater \\
\hline- Limit of Source Zone
\end{tabular}

\section{Graphic Scale}

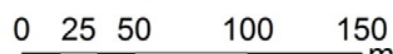

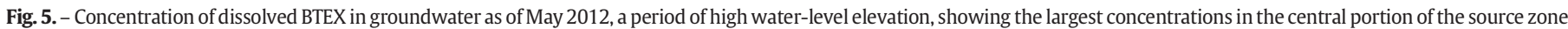

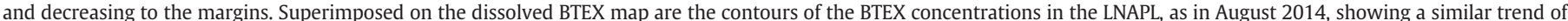
decreasing values towards the edge of the source zone. Circles indicate the location of the wells illustrated in Figs. 8, 9 and 10.

\subsection{Conceptual model}

A conceptual model is proposed to explain the observed LNAPL dissolution in the study area, where LNAPL saturation in the pores and the water table elevation with respect to the smear zone (Fig. 6) are the controlling factors.

The water table can fluctuate partially within (Fig. 6a), completely within (Fig. 6b) or above (Fig. 6c) the smear zone. The smear zone is

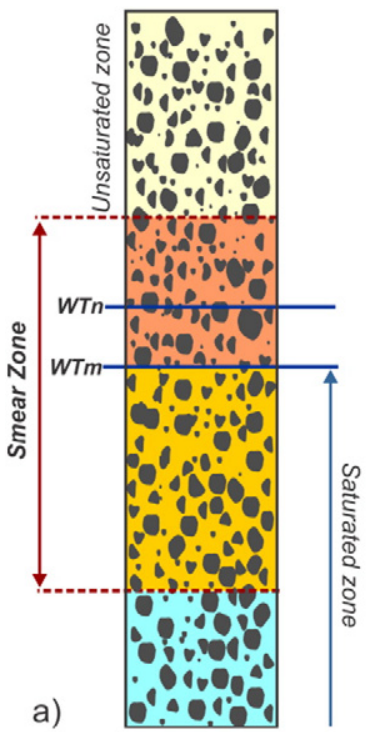

Saturated Smear zone (SSZ) - Saturated zone with LNAPL
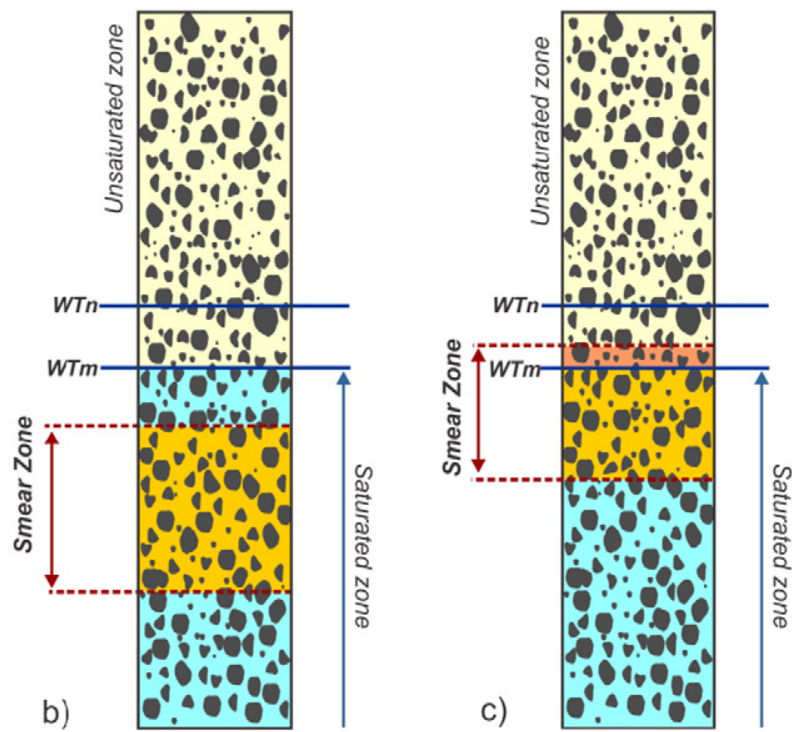

Unsaturated Smear zone (USZ) - Unsaturated zone with LNAPL

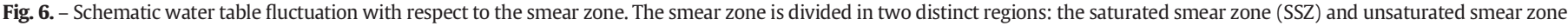

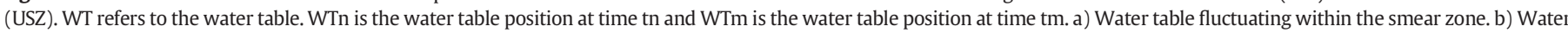
table fluctuating above the smear zone. c) Water table fluctuating partially within the smear zone. 
subdivided into two portions denominated the unsaturated smear zone (USZ) and saturated smear zone (SSZ), lying above and below the water table, respectively. LNAPL saturation of the SSZ is always higher than that of the USZ because LNAPL tends to migrate downward whenever it is freed. Contrary to saturation, the BTEX concentration of the SSZ LNAPL is lower than that of the USZ LNAPL because it is continually removed by mass transfer, as opposed to that in the unsaturated portion, where LNAPL is only occasionally in contact with water.

Although the loss of mass is expected to be elevated in the unsaturated zone due to volatilization, Yoon et al. (2002) and Petri et al. (2015) have shown that in the regions immediately above the saturated zone, the elevated water saturation reduces volatilization considerably. This is corroborated by the fact that successive investigations conducted in the study area have detected the presence of volatile organic compounds only near the saturated zone.

Based on field evidence, a direct dependency of the aqueous concentration trend over time is observed with respect to LNAPL saturation in pores. In the case of high LNAPL saturation, the mass of releasable BTEX in pores is large and the depletion trend is subtle. When LNAPL saturation in pores is low $(<20 \%)$, the BTEX mass is also low, resulting in relatively faster depletion of BTEX, following a fickian first-order decreasing trend. Low LNAPL saturation is mainly observed in the border regions of the source zone, whereas high saturation ( $>20 \%$ ) is more likely to occur in central regions.

Fig. 7 synthesizes the concentration trends based on possible combinations between LNAPL saturation and water table fluctuations with respect to the smear zone position.

Trend 1 illustrates a case in which the BTEX concentration oscillates in phase with water table fluctuations (Fig. 7a). This pattern occurs when the water table fluctuates within the smear zone. When the water table rises from the SSZ to the USZ, it promotes the saturation of part of the smear zone previously positioned in an unsaturated zone.
Because the residual LNAPL in the unsaturated zone is only occasionally in contact with water, this LNAPL is less depleted in BTEX, so more BTEX will be transferred from LNAPL to the water and, consequently, the BTEX concentration will increase as the water level rises. When the water table drops, it reduces the contribution of less depleted LNAPL of the USZ and, consequently, the aqueous BTEX concentration decreases.

Trend 2 shows an out-of-phase pattern of the BTEX concentration with respect to water table fluctuations (Fig. 7b). When the water table rises, it promotes the dilution of BTEX because the entire smear zone was already saturated. In the opposite direction, when the water level falls, the column of water above the smear zone decreases and the concentration of BTEX increases.

In the case of Trend 3, the water table fluctuates within and above the smear zone (Fig. 7c). Similar to both previous cases, because of the high saturation, LNAPL depletes slowly, resulting in a weak decreasing trend of the aqueous BTEX concentration. The resulting oscillation of BTEX will be a combination of the previous cases. Whenever the water table rises from the SSZ to the USZ, similar to that of Trend 1 (Fig. 7a), the BTEX fluctuation pattern will be in phase. When the water table rises well above the smear zone, the resulting pattern will be out of phase (Fig. 7b)

When the LNAPL saturation is low, depletion proceeds relatively faster. Hence, there will be a continuous transfer of the BTEX mass from LNAPL to the water and, for this reason, a continuous decrease in the BTEX concentration. Because more soluble compounds partition more efficiently to water, it is expected that the molar fraction of the BTEX in the remaining LNAPL will tend to decreases over time. The reduction of the BTEX molar fraction in LNAPL will then reduce the effective solubility of these compounds in water, resulting in a continuous decrease in the equilibrium BTEX concentration. Trends 4, 5 and 6 (Fig. $7 d$, e and f) reproduce the long-time tailing reduction in the

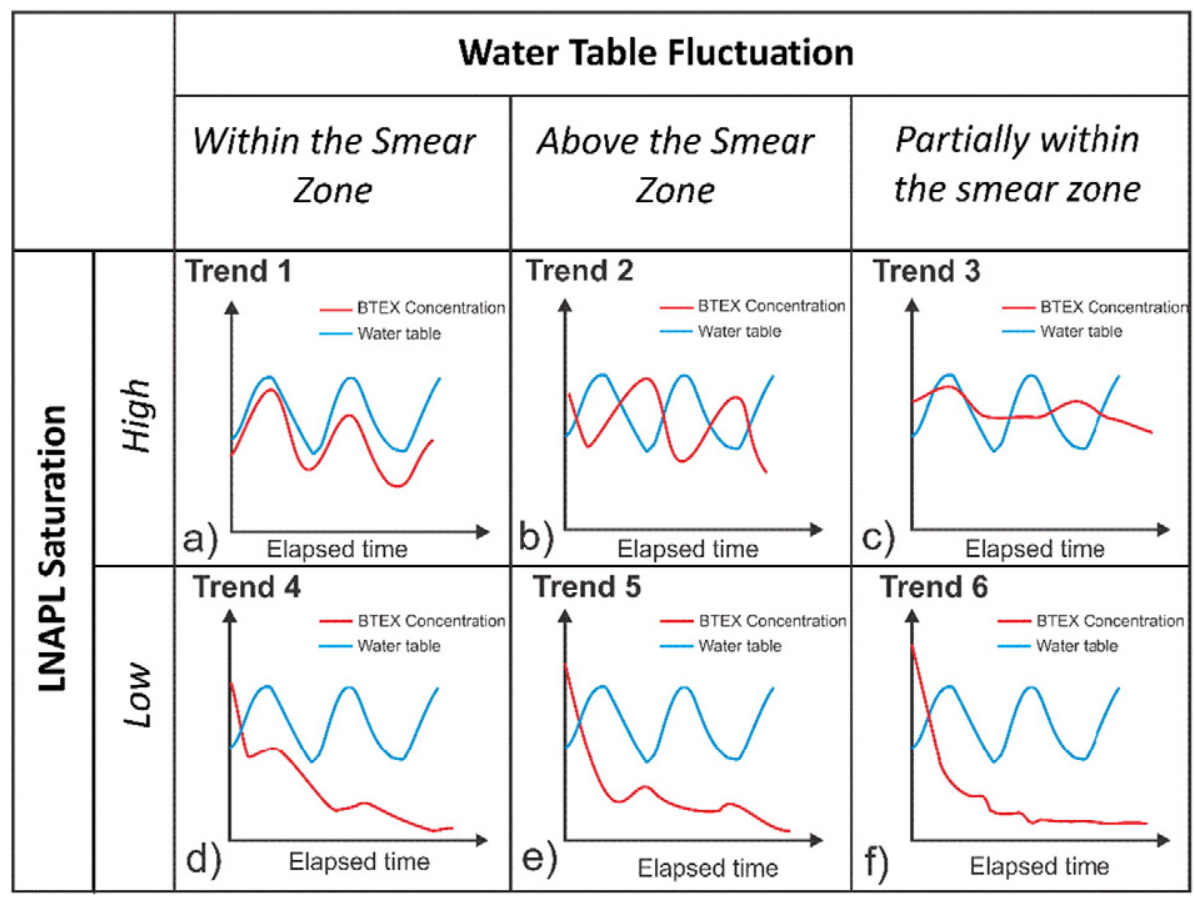

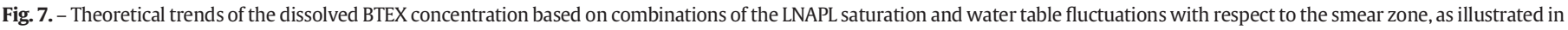

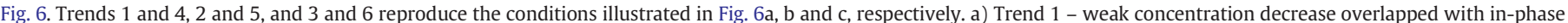

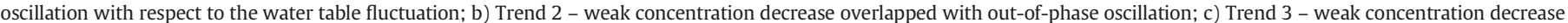

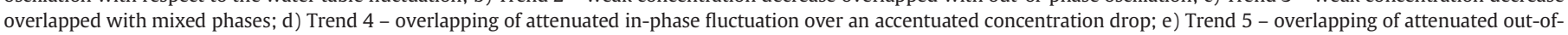
phase fluctuation over an accentuated concentration drop; and f) Trend 6 - overlapping of attenuated mixed phase fluctuations over an accentuated concentration drop. 
BTEX concentration over time. These trends are overlapped by BTEX oscillation as a result of water table fluctuations with respect to the smear zone position, such as that described for trends 1,2 and 3, respectively.

\subsection{Field application of numerical model}

To evaluate the proposed model, three simulations using the modified version of the algorithm of Liu et al. (2012) were performed and compared with field data. Although there are many possible trends due to the different combinations of saturation and smear zone positions, the performed simulations aimed to reproduce the three diferente wells with the most common concentration trends observed in field. The location of the monitoring well used in the simulated examples is illustrated in Fig. 5.

\subsubsection{Example 1}

In this example, the model was capable of reproducing the decline in the total xylene concentration over time, following a long-time tailing behavior (Fig. 8). This pattern reproduces the ideal case well, in which LNAPL saturation is low and the entire smear zone is below the water table (Fig. 7f, Trend 6).

Example 1 describes conditions commonly found near the border of the source zone in the study area, where LNAPL has a low saturation and low BTEX molar fraction. The USZ in this region is only $15 \mathrm{~cm}$ thick and the LNAPL saturation is $11 \%$ (Table 1 ).

\subsubsection{Example 2}

The simulation of Example 2 was capable of reproducing the observed temporal trend of total xylene concentration, oscillating inphase with cyclical water table fluctuations (Fig. 9), which is similar to that observed in Fig. 7a (Trend 1). This concentration trend is commonly observed in the central portions of the source zone and reproduces a condition in which the USZ is $60 \mathrm{~cm}$ thick, LNAPL saturation in the SSZ is $53 \%$ and the water table fluctuates completely within the smear zone (Table 1).

\subsubsection{Example 3}

The model was capable of reproducing the observed benzene concentration trend, oscillating out-of-phase with respect to the cyclical water table fluctuations (Fig. 10). This trend resembles that observed in Fig. 7b (Trend 2). Example 3 is also common in the central portion of the source zone of the study area and reproduces a condition in which the USZ is absent, LNAPL saturation in the SSZ is $42 \%$ and the water table fluctuates above the smear zone (Table 1 ).
Table 1

- Best fitted input parameter of the simulations presented in Examples 1, 2 and 3.

\begin{tabular}{llll}
\hline Model parameter & Example 1 & Example 2 & Example 3 \\
\hline Compound & Total Xylene & Total Xylene & Benzene \\
LNAPL Saturation in SSZ & 0.0112 & 0.53 & 0.452 \\
LNAPL Saturation in USZ & 0.04 & 0.09 & 0.09 \\
Sisub (moles/m3) & 1.4 & 1.4 & 22.79 \\
$\mathrm{Q}(\mathrm{m} 3 /$ day) & 0.025 & 0.023 & 0.028 \\
$\mathrm{~V}_{\mathrm{w}}(\mathrm{m} 3)$ & 0.22 & 0.28 & 0.2 \\
$\mathrm{~K}_{\mathrm{i}}(\mathrm{m} /$ day) & 0.04 & 0.05 & 0.05 \\
Activity coefficient & 1.0 & 1.0 & 1.0 \\
Interfacial area LNAPL/water $\left(\mathrm{m}^{2}\right)$ & 1.5 & 0.8 & 0.8 \\
Simulation time (days) & 1800 & 1640 & 2450 \\
Time step (days) & 1 & 1 & 1 \\
Initial molar fraction in SSZ & $7.50 \times 10^{-3}$ & $9.23 \times 10^{-3}$ & $3.50 \times 10{ }^{4}$ \\
Top of SSZ & 582 & 583.1 & 583.4 \\
Top of USZ & 582.15 & 584.5 & 583.4 \\
Coefficient of first-order decay & 11.55 & 11.55 & 11.55 \\
$\quad$ (days $^{-1}$ ) & & & \\
\hline
\end{tabular}

The proposed conceptual model of LNAPL dissolution combining cyclical water table fluctuations with LNAPL saturation was successfully tested.

The mass of releasable BTEX is directly related to the LNAPL mass hosted in the pores. Because the amount of BTEX solubilization is limited by the mass-transfer process, the ratio of transferred BTEX mass to water over the remaining BTEX in LNAPL is small for the case of a high LNAPL saturation smear zone, resulting in weak decreasing trend of the effective solubility and aqueous concentration of BTEX over time. However, the ratio of removed over remaining BTEX is significantly higher for a low saturation smear zone, resulting in a sharp decline in the molar fraction of BTEX in LNAPL and, consequently, a long-tail decreasing trend of aqueous BTEX.

The effect of water table fluctuations with respect to the smear zone position overlaps the overall decreasing trend due BTEX depletion in LNAPL (Fig. 7). When the water table fluctuates within the smear zone, the rising water table periodically reaches a region with less depleted LNAPL, promoting an increase in the BTEX concentration, resulting in an in-phase trend. In the case of the water table fluctuating most of the time above the smear zone, the rising water column above the smear zone will promote the dilution of the BTEX concentration and increase the concentration when the water table is down. Lastly, in the case of the water table fluctuating partially within the smear zone, the resulting pattern will be a combination of the in-phase and out-of-phase patterns - in-phase when the rising water table stays

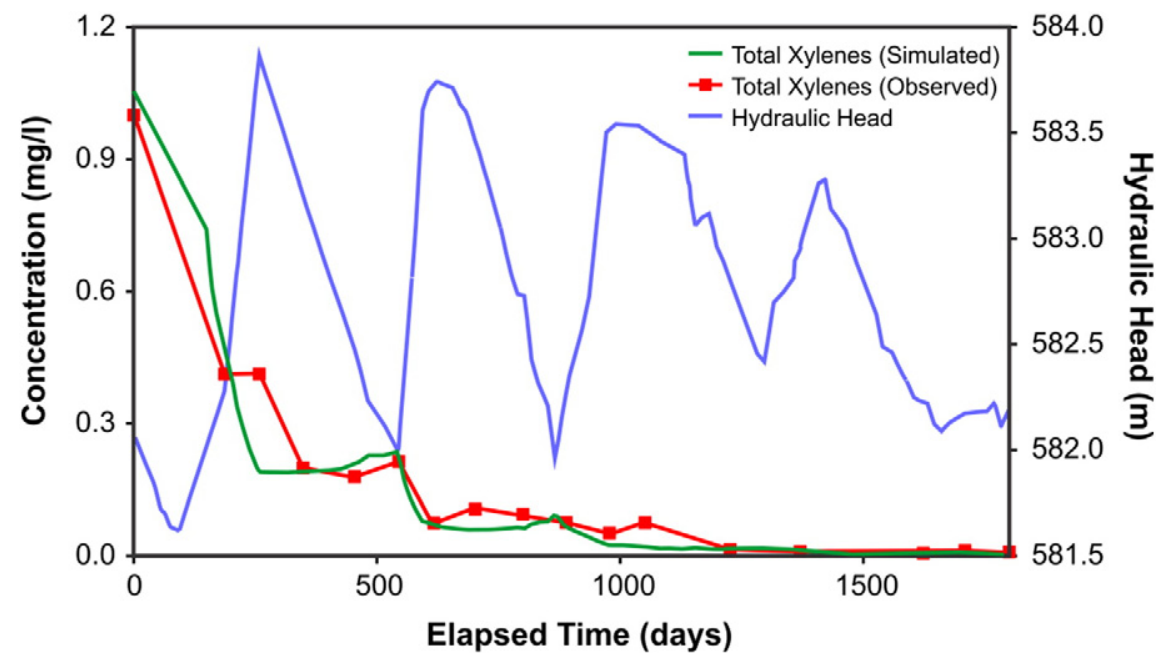

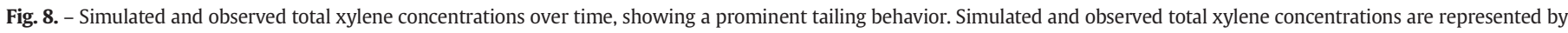

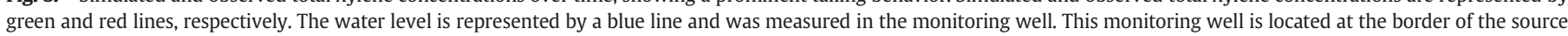
zone (Fig. 5, well A). 


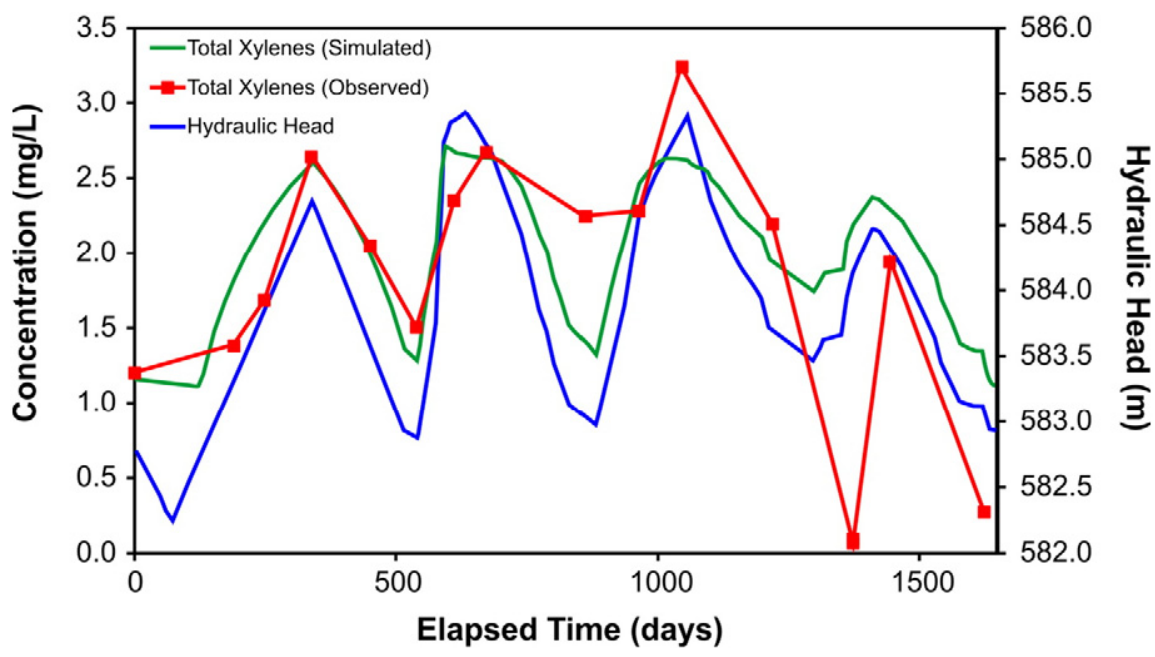

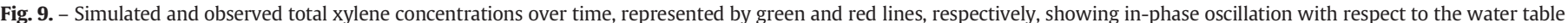

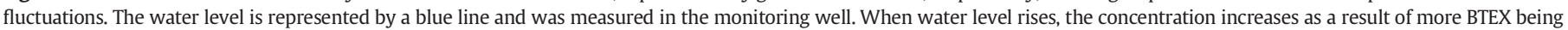

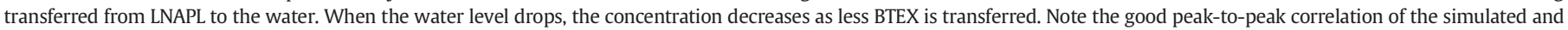
observed values. This monitoring well is located in the central portion of the source zone (Fig. 5, well B).

within the smear zone, and out-of-phase when the water table rises above the smear zone.

The simulation results obtained by combining saturation and water table fluctuations with respect to the water table satisfactorily reproduced the observed trend of an aqueous BTEX concentration in three representative wells (Figs. 8, 9 and 10). In Example1 (well A, Fig. 8 ), the algorithm was capable of precisely reproducing the observed total xylene concentration trend over almost five years. In examples 2 (well B, Fig. 9) and 3 (well C, Fig. 10), the peak-to-peak correlation was satisfactorily reproduced, and the magnitude of the simulated BTEX concentration did not match very well the observed analyses.

The partial fitting obtained for wells $B$ and $C$ can be attributed to the superposition of other factors taking place simultaneously during LNAPL "considered constant in the simulation. The flow rate can change in response to local hydraulic head variations induced by groundwater recharge or artificial pumping. The interfacial area is highly dependent on non-aqueous phase saturation (Held and Celia, 2001; Culligan et al., 2004; Brusseau et al., 2007; Brusseau et al., 2009); consequently, during cyclical events of drainage and imbibition of pores, the mass transfer rate will also change.

One important process that can affect the aqueous BTEX concentration is biodegradation, which was not considered in the simulation. Biodegradation kinetic changes in response to water table fluctuations was demonstrated in several works, e.g., Rainwater et al. (1993), Sinke et al. (1998), Rainwater et al. (1993), Dobson et al. (2007), Kehew and Lynch (2011) and Rezanezhad et al. (2014). These works suggest that biodegradation enhancement during episodes of a rising water table are attributed to aquifer oxygenation. It is then speculated that in some conditions, during the upward movement of the water table, the biodegradation kinetic becomes higher than the mass transfer coefficient, resulting in strong reduction in the BTEX concentration.

Algorithms explicitly based on the mass transfer equation, such as that of Liu et al. (2012), are better suited than those using empirically adjusted Sherwood-Gilland coefficients (Mobile et al., 2016). The results

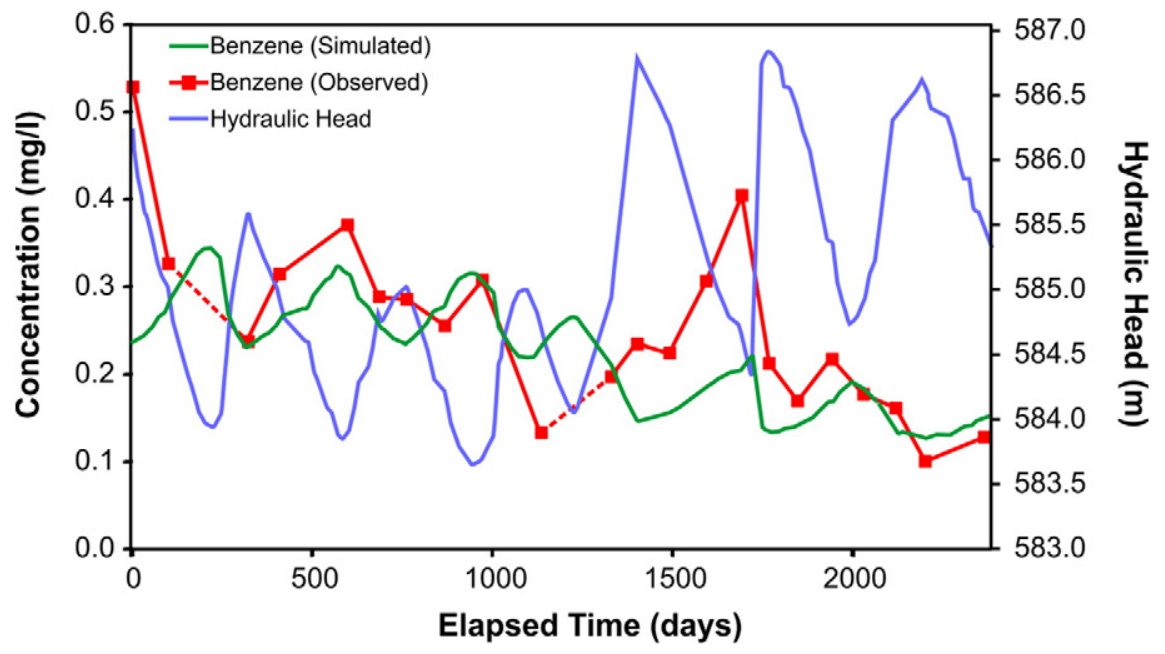

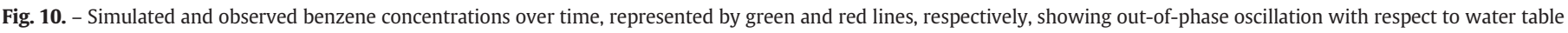

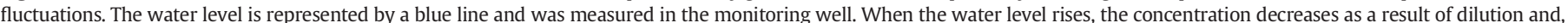

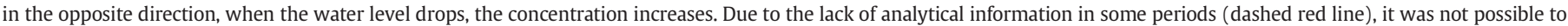

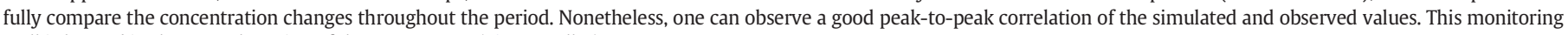
well is located in the central portion of the source zone (Fig. 5, well C). 
obtained in this work demonstrate the applicability of the mass transfer equation to REV elements that can be represented by individual cells in grids of numerical transport models.

The water table fluctuations illustrated in the conceptual model (Fig. 6) tentatively encompass the whole range of natural variabilities of hydrologic conditions, as rainfall patterns can vary significantly. Thus, for a long period of time, one might expect redistribution of the non-wetting phase in the pores, which may produce patterns other than those presented in Fig. 7. In the study area, for approximately 10 years (2003 to 2014), rainfall intensity and periodicity did not change much (Fig. 2) except in the year 2014, when a severe drought affected the region. One consequence of the severe drop in the water table is the expansion of the smear zone width produced by downward migration and redistribution of LNAPL over a larger vertical interval. This downward LNAPL redistribution reduces the LNAPL saturation and favors subsequent water table fluctuation oscillating within the smear zone.

Similar patterns of the BTEX concentration changing over time have been described elsewhere (Davis et al., 1993; Kehew and Lynch, 2011 and Zhou et al., 2015). Kehew and Lynch (2011) presented three similar BTEX trends from a contaminated site located in Michigan (USA), suggesting that these patterns are widespread and can be explained by the conceptual model proposed in the present work.

Mass transfer continually removes the BTEX mass from LNAPL entrapped in the pores with the aqueous BTEX mineralized by native bacterial metabolism. The quantification of BTEX mass removal is the key issue in natural source zone depletion (NSZD) assessment (ITRC, 2009); however in many cases, the available monitoring data are scarce and cannot identify a clear decreasing concentration tendency, inducing incorrect interpretations. As demonstrated, seasonal effects, such as water table fluctuations, can promote considerable LNAPL dissolution and consequently significant changes in the BTEX concentration over time. Therefore, this phenomenon should not be ignored in long-term prediction models.

\section{Conclusions}

Mass transfer from entrapped LNAPL to groundwater has been successfully investigated. The aqueous BTEX concentration trend in the source zone can be conveniently described as an overall long-term decreasing trend, governed by LNAPL saturation in the pores modulated by seasonal water table fluctuations.

In the high LNAPL saturation zone, the mass of BTEX transferred to water is comparably low with respect to the remaining BTEX in the LNAPL; consequently, a weak decreasing trend will occur. In the low LNAPL saturation zone, the ratio of transferred BTEX mass over the remaining BTEX in LNAPL is considerably higher, resulting in a significant decreasing trend of the aqueous BTEX concentration.

When the water table fluctuates partially within the smear zone, the BTEX concentration will display an in-phase trend because water is periodically in contact with less depleted LNAPL. When the water table fluctuates most of the time above the smear zone, the rising water table will dilute the BTEX concentration, imposing an out-ofphase trend. Finally, when the water level fluctuates partially within the smear zone, the BTEX concentration trend will display an out-ofphase behavior when the water table rises above the smear zone and an in-phase trend when the water table oscillates within the smear zone.

\section{Acknowledgments}

We gratefully acknowledge Fundação para o Desenvolvimento da UNESP - FUNDUNESP (1425/2006), Laboratory of Basin Studies LEBAC/UNESP and Petróleo Brasileiro S/A - PETROBRAS (2052/2012) for their financial and technical support and thank Rogério Bordignon for his assistance during fieldwork. We would like to thank the anonymous reviewers for their helpful comments and suggestions.

\section{References}

Anderson, M.R., Johnson, R.L., Pankow, J.F., 1992. Dissolution of dense chlorinated solvents into ground water: 1 . Dissolution from a well-defined residual source. Ground Water 30 (2):250-256. http://dx.doi.org/10.1111/j.1745-6584.1992.tb01797.x.

Banerjee, S., 1984. Solubility of organic mixtures in water. Environ. Sci. Technol. 18 (8): 587-591. http://dx.doi.org/10.1021/es00126a004.

Borden, R.C., Kao, C.M., 1992. Evaluation of groundwater extraction for remediation of petroleum-contaminated aquifers. Water Environ. Res. 64 (1):28-36. http://dx.doi.org/ 10.2175/WER.64.1.5.

Bordignon, R., Teramoto, E.H., Chang, K.H., 2015. Caracterização isotópica de CO2 dissolvido em águas subterrâneas em área contaminada por querosene de aviação, município de Paulínia, SP. Águas Subterrâneas. Vol. 29(3):pp. 301-314. http://dx doi.org/10.14295/ras.v29i3.27979.

Brusseau, M.L., Peng, S., Schnaar, G., Murao, A., 2007. Measuring air-water interfacial areas with X-ray microtomography and interfacial partitioning tracer tests. Environ. Sci. Technol. 41 (6):1956-1961. http://dx.doi.org/10.1021/es061474m.

Brusseau, M.L., Narter, M., Schnaar, G., Marble, J., 2009. Measurement and estimation of organic-liquid/water interfacial areas for several natural porous media. Environ. Sci. Technol. 43 (10):3619-3625. http://dx.doi.org/10.1021/es8020827.

Charbeneau, R.J., 2007. LNAPL Distribution and Recovery Model, LDRM. Distribution and Recovery of Petroleum Hydrocarbon Liquids in Porous Media. Vol. 4760. API Publication Number, p. 1.

Chatzis, I., Dullien, F.A.L., 1983. Dynamic immiscible displacement mechanisms in pore doublets: Theory versus experiment. J. Colloid Interface Sci. 91 (1):199-222. http:// dx.doi.org/10.1016/0021-9797(83)90326-0.

Cho, J., Annable, M.D., 2005. Characterization of pore scale NAPL morphology in homogeneous sands as a function of grain size and NAPL dissolution. Chemosphere 61 (7): 899-908. http://dx.doi.org/10.1016/j.chemosphere.2005.04.042.

Cho, J., Annable, M.D., Rao, P.S.C., 2005. Measured mass transfer coefficients in porous media using specific interfacial area. Environ. Sci. Technol. 39 (20):7883-7888. http://dx.doi.org/10.1021/es0505043.

Chrysikopoulos, C.V., Lee, K.Y., 1998. Contaminant transport resulting from multicomponent nonaqueous phase liquid pool dissolution in three-dimensional subsurface formations. J. Contam. Hydrol. 31 (1):1-21. http://dx.doi.org/10.1016/S01697722(97)00053-3.

Cline, P.V., Delfino, J.J., Rao, P.S.C., 1991. Partitioning of aromatic constituents into water from gasoline and other complex solvent mixtures. Environ. Sci. Technol. 25 (5): 914-920. http://dx.doi.org/10.1021/es00017a013.

Colombani, N., Mastrocicco, M., Gargini, A., Davis, G.B., Prommer, H., 2009. Modelling the fate of styrene in a mixed petroleum hydrocarbon plume. J. Contam. Hydrol. 105 (1): 38-55. http://dx.doi.org/10.1016/j.jconhyd.2008.11.005.

Culligan, K.A., Wildenschild, D., Christensen, B.S., Gray, W.G., Rivers, M.L., Tompson, A.F., 2004. Interfacial area measurements for unsaturated flow through a porous medium. Water Resour. Res. 40 (12). http://dx.doi.org/10.1016/j.advwatres.2005.03.021.

Davis, G.B., Johnston, C.D., Thierrin, J., Power, T.R., Patterson, B.M., 1993. Characterizing the distribution of dissolved and residual NAPL petroleum hydrocarbons in unconfined aquifers to effect remediation. J. Aust. Geol. Geophys. 14, 89-94.

Delin, G.N., Healy, R.W., Lorenz, D.L., Nimmo, J.R., 2007. Comparison of local-to regionalscale estimates of ground-water recharge in Minnesota, USA. J. Hydrol. 334 (1): 231-249. http://dx.doi.org/10.1016/j.jhydrol.2006.10.010.

Dobson, R., Schroth, M.H., Zeyer, J., 2007. Effect of water-table fluctuation on dissolution and biodegradation of a multi-component, light nonaqueous-phase liquid. J. Contam. Hydrol. 94 (3):235-248. http://dx.doi.org/10.1016/j.jconhyd.2007.07.007.

Eberhardt, C., Grathwohl, P., 2002. Time scales of organic contaminant dissolution from complex source zones: Coal tar pools vs. blobs. J. Contam. Hydrol. 59 (1):45-66. http://dx.doi.org/10.1016/S0169-7722(02)00075-X.

Farr, A.M., Houghtalen, R.J., McWhorter, D.B., 1990. Volume estimation of light nonaqueous phase liquids in porous media. Groundwater 28 (1):48-56. http://dx.doi.org/10. 1111/j.1745-6584.1990.tb02228.x.

Farthing, M.W., Seyedabbasi, M.A., Imhoff, P.T., Miller, C.T., 2012. Influence of porous media heterogeneity on nonaqueous phase liquid dissolution fingering and upscaled mass transfer. Water Resour. Res. 48 (8). http://dx.doi.org/10.1029/2011WR011389.

Geller, J.T., Hunt, J.R., 1993. Mass transfer from nonaqueous phase organic liquids in water-saturated porous media. Water Resour. Res. 29 (4):833. http://dx.doi.org/10. 1029/92WR02581.

Ghoshal, S., Ramaswami, A., Luthy, R.G., 1996. Biodegradation of naphthalene from coal tar and heptamethylnonane in mixed batch systems. Environ. Sci. Technol. 30 (4): 1282-1291. http://dx.doi.org/10.1021/es950494d.

Grant, G.P., Gerhard, J.I., 2007. Simulating the dissolution of a complex dense nonaqueous phase liquid source zone: 1 . Model to predict interfacial area. Water Resour. Res. 43 (12). http://dx.doi.org/10.1029/2007WR006038.

Healy, R.W., Cook, P.G., 2002. Using groundwater levels to estimate recharge. Hydrogeol. J. 10 (1):91-109. http://dx.doi.org/10.1007/s10040-001-0178-0.

Healy, R.W., Cook, P.G., 2002. Using groundwater levels to estimate recharge. Hydrogeol. J. 10 (1), 91-109. doi: 10.1007/s10040-001-0178-0. Held, R.J., Celia, M.A., 2001. Modeling support of functional relationships between capillary pressure, saturation, interfacial area and common lines. Adv. Water Resour. 24 (3):325-343. http://dx.doi.org/10. 1016/S0309-1708(00)00060-9.

Huntley, D., Hawk, R.N., Corley, H.P., 1994. Nonaqueous phase hydrocarbon in a finegrained sandstone: 1 . Comparison between measured and predicted saturations and mobility. Ground Water 32 (4):626-634. http://dx.doi.org/10.1111/j.17456584.1994.tb00898.x.

Illangasekare, T.H., Armbruster III, E.J., Yates, D.N., 1995. Non-aqueous-phase fluids in heterogeneous aquifers-experimental study. J. Environ. Eng. 121 (8):571-579. http://dx. doi.org/10.1061/(ASCE)0733-9372(1995)121:8(571). 
Imhoff, P.T., Jaffé, P.R., Pinder, G.F., 1994. An experimental study of complete dissolution of a nonaqueous phase liquid in saturated porous media. Water Resour. Res. 30 (2): 307-320. http://dx.doi.org/10.1029/93WR02675.

ITRC, 2009. Evaluating LNAPL Remedial Technologies for Achieving Project Goals LNAPL-2 (Washington, D.C. Available at http://www.itrcweb.org/Team/Public?TeamID=18).

Jeong, J., Charbeneau, R.J., 2014. An analytical model for predicting LNAPL distribution and recovery from multi-layered soils. J. Contam. Hydrol. 156:52-61. http://dx.doi.org/10. 1016/j.jconhyd.2013.09.008.

Kehew, A.E., Lynch, P.M., 2011. Concentration trends and water-level fluctuations at underground storage tank sites. Environ. Earth Sci. 62 (5):985-998. http://dx.doi.org/ 10.1007/s12665-010-0583-6.

Kemblowski, M.W., Chiang, C.Y., 1990. Hydrocarbon thickness fluctuations in monitoring wells. Ground Water 28 (2):244-252. http://dx.doi.org/10.1111/j.1745-6584.1990. tb02252.x.

Kokkinaki, A., O'Carroll, D.M., Werth, C.J., Sleep, B.E., 2013. An evaluation of SherwoodGilland models for NAPL dissolution and their relationship to soil properties. J. Contam. Hydrol. 155:87-98. http://dx.doi.org/10.1016/j.jconhyd.2013.09.007.

Kueper, B.H., Abbott, W., Farquhar, G., 1989. Experimental observations of multiphase flow in heterogeneous porous media. J. Contam. Hydrol. 5 (1):83-95. http://dx.doi. org/10.1016/0169-7722(89)90007-7.

Lee, K.Y., Chrysikopoulos, C.V., 1998. NAPL pool dissolution in stratified and anisotropic porous formations. J. Environ. Eng. 124 (9):851-862. http://dx.doi.org/10.1061/ (ASCE)0733-9372(1998)124:9(851)\#sthash.CzfbQh77.dpuf.

Lee, K.Y., Chrysikopoulos, C.V., 2006. Dissolution of a multicomponent DNAPL pool in an experimental aquifer. J. Hazard. Mater. 128 (2):218-226. http://dx.doi.org/10.1016/ S0043-1354(02)00097-0.

Lekmine, G., Bastow, T.P., Johnston, C.D., Davis, G.B., 2014. Dissolution of multi-component LNAPL gasolines: The effects of weathering and composition. J. Contam. Hydrol. 160:1-11. http://dx.doi.org/10.1016/j.jconhyd.2014.02.003.

Lenhard, R.J., Parker, J.C., 1990. Estimation of free hydrocarbon volume from fluid levels in monitoring wells. Ground Water 28 (1):57-67. http://dx.doi.org/10.1111/j.17456584.1990.tb02229.x.

Liu, L., Maier, U., Grathwohl, P., Haderlein, S.B., 2012. Contaminant mass transfer from NAPLs to water studied in a continuously stirred flow-through reactor. J. Environ. Eng. 138 (8):826-832. http://dx.doi.org/10.1061/(ASCE)EE.1943-7870.0000528.

Lundegard, P.D., Mudford, B.S., 1998. LNAPL volume calculation: Parameter estimation by nonlinear regression of saturation profiles. Ground Water Monit. Remidiat. 18 (3): 88-93. http://dx.doi.org/10.1080/15275920490454346.

Luthy, R.G., Ramaswami, A., Ghoshal, S., Merkel, W., 1993. Interfacial films in coal tar nonaqueous-phase liquid-water systems. Environ. Sci. Technol. 27 (13):2914-2918. http://dx.doi.org/10.1021/es00049a035.

Mackay, D., Shiu, W.Y., Maijanen, A., Feenstra, S., 1991. Dissolution of non-aqueous phase liquids in groundwater. J. Contam. Hydrol. 8 (1):23-42. http://dx.doi.org/10.1016 0169-7722(91)90007-N.

Maréchal, J.C., Dewandel, B., Ahmed, S., Galeazzi, L., Zaidi, F.K., 2006. Combined estimation of specific yield and natural recharge in a semi-arid groundwater basin with irrigated agriculture. J. Hydrol. 329 (1):281-293. http://dx.doi.org/10.1016/j.jhydrol.2006.02. 022.

Marinelli, F., Durnford, D.S., 1996. LNAPL thickness in monitoring wells considering hysteresis and entrapment. Ground Water 34 (3):405-414. http://dx.doi.org/10.1111/j. 1745-6584.1996.tb02021.x

Mayer, A.S., Zhong, L., Pope, G.A., 1999. Measurement of mass-transfer rates for surfactant-enhanced solubilization of nonaqueous phase liquids. Environ. Sci. Technol. 33 (17):2965-2972. http://dx.doi.org/10.1021/es9813515.

Miller, C.T., Poirier-McNeill, M.M., Mayer, A.S., 1990. Dissolution of trapped nonaqueous phase liquids: Mass transfer characteristics. Water Resour. Res. 26 (11):2783-2796. http://dx.doi.org/10.1029/WR026i011p02783.

Mobile, M., Widdowson, M., Stewart, L., Nyman, J., Deeb, R., Kavanaugh, M., Gallagher, D 2016. In-situ determination of field-scale NAPL mass transfer coefficients: Performance, simulation and analysis. J. Contam. Hydrol. 187:31-46. http://dx.doi.org/10. 1016/j.jconhyd.2016.01.010.

Neto, D.C., Chang, H.K., van Genuchten, M.T., 2016. A mathematical view of water table fluctuations in a shallow aquifer in Brazil. Ground Water 54 (1):82-91. http://dx. doi.org/10.1111/gwat.12329.

Pede, M.A.Z., 2009. Flutuação do lençol freático e sua implicação na recuperação de hidrocarbonetos: um estudo de caso, Doctoral Dissertion in Geosciences and Environment Program - University of São Paulo state.

Petri, B.G., Fučík, R., Illangasekare, T.H., Smits, K.M., Christ, J.A., Sakaki, T., Sauck, C.C., 2015. Effect of NAPL source morphology on mass transfer in the vadose zone. Ground Water 53 (5):685-698. http://dx.doi.org/10.1111/gwat.12284.

Porter, M.L., Wildenschild, D., Grant, G., Gerhard, J.I., 2010. Measurement and prediction of the relationship between capillary pressure, saturation, and interfacial area in a NAPL-water-glass bead system. Water Resour. Res. 46 (8). http://dx.doi.org/10. 1029/2009WR007786.
Powers, S.E., Abriola, L.M., Weber W. 1992. An experimental investigation of nonaqueous phase liquid dissolution in saturated subsurface systems: Steady state mass transfer rates. Water Resour. Res. 28 (10):2691-2705. http://dx.doi.org/10.1029/ 92WR00984.

Powers, S.E., Abriola, L.M., Weber, W.J., 1994. An experimental investigation of nonaqueous phase liquid dissolution in saturated subsurface systems: Transient mass transfer rates. Water Resour. Res. 30 (2):321-332. http://dx.doi.org/10.1029/93WR02923.

Rainwater, K., Mayfield, M.P., Heintz, C., Claborn, B.J., 1993. Enhanced in situ biodegradation of diesel fuel by cyclic vertical water table movement: Preliminary studies. Water Environ. Res. 65 (6):717-725. http://dx.doi.org/10.1029/2009WR007786.

Reddi, L.N., Han, W., Banks, M.K., 1998. Mass loss from LNAPL pools under fluctuating water table conditions. J. Environ. Eng. 124 (12):1171-1177. http://dx.doi.org/10. 1061/(ASCE)0733-9372(1998)124:12(1171).

Rezanezhad, F., Couture, R.M., Kovac, R., O'Connell, D., Van Cappellen, P., 2014. Water table fluctuations and soil biogeochemistry: An experimental approach using an automated soil column system. J. Hydrol. 509:245-256. http://dx.doi.org/10.1016/j. jhydrol.2013.11.036

Saba, T., Illangasekare, T.H., 2000. Effect of groundwater flow dimensionality on mass transfer from entrapped nonaqueous phase liquid contaminants. Water Resour. Res. 36 (4):971-979. http://dx.doi.org/10.1029/1999WR900322.

Saba, T., Illangasekare, T.H., Ewing, J., 2001. Investigation of surfactant-enhanced dissolution of entrapped nonaqueous phase liquid chemicals in a two-dimensional groundwater flow field. J. Contam. Hydrol. 51 (1):63-82. http://dx.doi.org/10.1016/S01697722(01)00122-X.

Saenton, S., Illangasekare, T.H., Soga, K., Saba, T.A., 2002. Effects of source zone heterogeneity on surfactant-enhanced NAPL dissolution and resulting remediation endpoints. J. Contam. Hydrol. 59 (1):27-44. http://dx.doi.org/10.1007/s13201-0130090-5.

Saripalli, K.P. Rao, P.S.C., Annable, M.D., 1998. Determination of specific NAPL-water interfacial areas of residual NAPLs in porous media using the interfacial tracers technique. J. Contam. Hydrol. 30 (3):375-391. http://dx.doi.org/10.1016/S01697722(97)00052-1.

Seagren, E.A., Rittmann, B.E., Valocchi, A.J., 1999. An experimental investigation of NAPL pool dissolution enhancement by flushing. J. Contam. Hydrol. 37 (1):111-137. http://dx.doi.org/10.1016/S0169-7722(98)00157-0.

Sinke, A.J.C., Dury, O., Zobrist, J., 1998. Effects of a fluctuating water table: Column study on redox dynamics and fate of some organic pollutants. J. Contam. Hydrol. 33 (1): 231-246. http://dx.doi.org/10.1016/S0169-7722(98)00072-2.

Teramoto, E.H., 2015. Estudo da efetividade da atenuação natural de compostos BTEX em área contaminada por querosene de aviação, Doctoral Dissertion in Geosciences and Environment Program - University of São Paulo state.

Teramoto, E.H., Chang, H.K., 2008. Caracterização Hidrogeológica e Simulação Numérica em Área do Distrito Industrial de Paulínia, SP. Águas Subterrâneas. Vol. 22(1): pp. 129-144. http://dx.doi.org/10.14295/ras.v22i1.17123.

Teramoto, E.H., Chang, H.K., 2016. Reactive Transport Model for Biodegradation of Jet Fuel in Lateritic Aquifer. Goldschmidt Abstracts, 2016. Vol. 3108 (https:// goldschmidt.info/2016//uploads/abstracts/originalPDFs/541.pdf).

U.S. Environmental Protection Agency, 1998. Groundwater Sampling Standard Operating Procedures. U.S. Environmental Protection Agency, Region II, New York.

Yoon, H., Kim, J.H., Liljestrand, H.M., Khim, J., 2002. Effect of water content on transient nonequilibrium NAPL-gas mass transfer during soil vapor extraction. J. Contam. Hydrol. 54 (1):1-18. http://dx.doi.org/10.1016/S0169-7722(01)00164-4.

Zhang, C., Werth, C.J., Webb, A.G., 2002. A magnetic resonance imaging study of dense nonaqueous phase liquid dissolution from angular porous media. Environ. Sci. Technol. 36 (15):3310-3317. http://dx.doi.org/10.1021/es011497v.

Zhang, C., Werth, C.J., Webb, A.G., 2007. Characterization of NAPL source zone architecture and dissolution kinetics in heterogeneous porous media using magnetic resonance imaging. Environ. Sci. Technol. 41 (10):3672-3678. http://dx.doi.org/10.1021/ es061675q

Zhang, C., Yoon, H., Werth, C.J., Valocchi, A.J., Basu, N.B., Jawitz, J.W., 2008. Evaluation of simplified mass transfer models to simulate the impacts of source zone architecture on nonaqueous phase liquid dissolution in heterogeneous porous media. J. Contam. Hydrol. 102 (1):49-60. http://dx.doi.org/10.1016/j.jconhyd.2008.05.007.

Zhong, L., Mayer, A.S., Pope, G.A., 2003. The effects of surfactant formulation on nonequilibrium NAPL solubilization. J. Contam. Hydrol. 60 (1):55-75. http://dx.doi.org/10. 1016/S0169-7722(02)00063-3.

Zhou, A.X., Zhang, Y.L., Dong, T.Z., Lin, X.Y., Su, X.S., 2015. Response of the microbial community to seasonal groundwater level fluctuations in petroleum hydrocarbon-contaminated groundwater. Environ. Sci. Pollut. Res. 22 (13):10094-10106. http://dx. doi.org/10.1007/s11356-015-4183-6. 